Research Article

\section{A review on efficacy of Cissus quadrangularis in pharmacological mechanisms}

\author{
Sadiya Zaki ${ }^{1}, \mathbf{R}$ Malathi ${ }^{2}$, V Latha ${ }^{3}$ and Sibi G ${ }^{1 *}$ \\ ${ }^{1}$ Department of Biotechnology, Indian Academy Degree College-Autonomous, Bangalore, India \\ ${ }^{2}$ Department of Biochemistry, Indian Academy Degree College-Autonomous, Bangalore, India \\ ${ }^{3}$ Department of Chemistry, Indian Academy Degree College-Autonomous, Bangalore, India
}

\author{
More Information \\ *Address for Correspondence: Sibi G \\ Head of the Department, Department of \\ Biotechnology, Indian Academy Degree College- \\ Autonomous, Bangalore, India, \\ Tel: 99864 52875; Email: gsibii@gmail.com \\ Submitted: 06 October 2020 \\ Approved: 03 December 2020 \\ Published: 04 December 2020 \\ How to cite this article: Zaki S, Malathi R, \\ Latha V, Sibi G. A review on efficacy of Cissus \\ quadrangularis in pharmacological mechanisms. \\ Int J Clin Microbiol Biochem Technol. 2020; 3: \\ 049-053. \\ DOI: 10.29328/journal.ijcmbt.1001016
}

Copyright: @ 2020 Zaki S, et al. This is an open access article distributed under the Creative Commons Attribution License, which permits unrestricted use, distribution, and reproduction in any medium, provided the original work is properly cited.

Keywords: Cissus quadrangularis; Osteogenic; Anti-inflammatory; Antimicrobial; Bone turnover

Check for updates

OPEN ACCESS

\section{Introduction}

Cissus quadrangularis is a tendril-climbing shrub with stout, fleshy quadrangular stems. The leaf portion constitutes only $5 \%-8 \%$ of the aerial plant parts; the fleshy, green stem is the major portion. The plant is widely distributed throughout tropical and subtropical regions of the world such as India, Sri Lanka, South Africa, Thailand, Java and Philippines. The entire parts (root, stem, and leaves) of the plant have been cited in both Ayurvedic and Unani systems for its medicinal values. Due to its bone ligation properties, the plant is referred to as 'Asthisamharaka' in Sanskrit. C. quadrangularis belonging to Vitaceae family is one of the most widely used for the treatment of piles, anorexia, indigestion, chronic ulcers, asthma, otorrhoea, wounds and in augmenting fracture healing process [1-3]. The stout quadrangular stem is traditionally used for treatment of bone fracture, piles, chronic ulcers, asthma, scurvy, irregular menstruation, constipation and blindness.

The major constituents found in the plant are ascorbic acid, carotene A, ketosteroid, calcium, triterpenoids. It has been reported to contain three unsymmetric tetracyclic triterpenoids along with $\beta$-sitosterol, $\beta$-amyrin, and $\beta$-amyrone. In addition, it also contains flavonoids, phytosterols, $\delta$-amyrin, $\delta$-amyron, resveratrol, piceatannol, pallidol, parthenocissine, quadragularins and water-soluble glycosides [4-8]. The unique chemical constituents of Cissus -novel flavonoids and indanes, as well as phytosterols and ketosteroids-have shown promise as powerful and efficient antioxidants. The plant is reported to contain inorganic minerals like calcium, iron, copper, zinc and potassium. Though the plant is used to treat various ailments over the years there is a lack of systematic review and meta-analysis of the medicinal use of this plant. This study aims to fill this gap through a systematic review of clinical evidence to determine the efficacy of $C$. quadrangularis.

\section{Sources and methodology}

The search was done in electronic databases of PubMed, Scopus, ScienceDirect, Web of Science and Google Scholar for studies using the key terms: Cissus quadrangularis, antimicrobial, anti-obesity, anti-inflammatory, bone resorption and antioxidant. The inclusion was based reported articles on pharmacological activities of $C$. quadrangularis which are discussed in detail. All the data were extracted and explained in respective subheadings.

\section{Antimicrobial activity}

Chloroform extract of $C$. quadrangularis $\mathrm{L}$. was reported to exhibit Helicobactericidal activity under in vitro conditions [9]. In one study [10], the ethyl acetate extract and methanol 
extract of both fresh and dry stems of $C$. quadrangularis exhibited antimicrobial activity against Gram-positive bacteria, including Bacillus subtilis, Bacillus cereus, Staphylococcus aureus, and Streptococcus species. Copper oxide nanoparticles (CuO NPs) synthesized using C. quadrangularis acts as better fungicidal agent against Aspergillus niger and Aspergillus flavus as reported earlier [11]. Similarly, silver chloride nanoparticles synthesized using leaf extract of $C$. quadrangularis exhibited better antibacterial activity against Streptococcus pyogenes, Staphylococcus aureus, Escherichia coli and Proteus vulgaris than tetracycline [12]. C. quadrangularis mediated calcium oxide nanoparticles showed maximum inhibition on $E$. coli [13]. The minimum inhibitory concentration was about 7.8 $\mu \mathrm{g}$ for Staphylococcus aureus, Escherichia coli, Klebsiella pneumoniae and Pseudomonas aeruginosa followed by $15.6 \mu \mathrm{g}$ for Salmonella typhi, Shigella dysenteriae and Vibrio cholerae.

Methanolic extracts of aerial parts of $C$. quadrangularis were tested for in vitro anthelmintic activity against Haemonchus contortus, the causative agent of Haemonchosis, is a nematode parasite that feeds on blood of small ruminant animals and causes anaemia, anorexia, reduced growth, and eventual death of host animals [14]. The extract produced a dose dependent anthelmintic activity in both adult motility assay and egg hatch inhibition assay. Further, C. quadrangularis induced 88\% egg hatching inhibitory effect at $1 \mathrm{mg} / \mathrm{ml}$ concentration. Cysteine protease from $C$. quadrangularis showed zone of inhibition of 21 and $20 \mathrm{~mm}$ against Bacillus cereus and Bacillus megaterium respectively at $4.74 \mathrm{U} \mathrm{ml}^{-1}$ [15]. In another study, methanolic extract of $C$. quadrangularis was explored for antiviral activity against HSV type1 and 2 and Vero cells. Both HSV1 and HSV2 showed more sensitivity at 1: 400 dilution [16].

\section{Anti-diabetic activity}

Lekshmi, et al. [17,18] suggested the anti-diabetic potential of $C$. quadrangularis stem extract, mediated through the modulation of the antioxidant defence system. The ethyl acetate fraction is rich in quercetin supplementation of the plant might be beneficial as a food supplement for the attenuation of diabetic complications. Further, antidiabetic activity of the plant is associated with potentiating the antioxidant defense system and suppressing inflammatory responses.

\section{Anti-inflammatory activity}

Panthong, et al. [19] revealed the anti-inflammatory effect of $C$. quadrangularis which is associated with luteolin, and by $\beta$-sitosterol. Likewise, methanolic root extract of $C$. quadrangularis showed potent activity of 4.16 at $50 \mathrm{mg} /$ $\mathrm{kg}$ dose level [20]. Ethyl acetate extract of C. quadrangularis potently inhibited lipopolysaccharide-induced nitric oxide production in RAW 264.7 macrophage cells in a dosedependent manner [21]. The mRNA and protein expressions of inducible nitric oxide synthase were suppressed also by the extract as was p65 NF- $\kappa \mathrm{B}$ nuclear translocation. Further study demonstrated that the extract by itself induced heme oxygenase- 1 gene expression at the protein and mRNA levels in dose- and time-dependent manner. Similarly, acetone extract of the plant showed cycloxygenase and 5-lipoxygenase inhibition with IC50 values of $7 \mu \mathrm{g} / \mathrm{ml}, 0.4 \mu \mathrm{g} / \mathrm{ml}$, and $20 \mu \mathrm{g} /$ $\mathrm{ml}$ for cycloxygenase-1, cycloxygenas-2 and 5-lipoxygenase respectively. It also showed anti-inflammatory activity on RAW 264.7 cell line with IC50 value $65 \mu \mathrm{g} / \mathrm{ml}$. In addition to this, the extract exhibited inhibition of proinflammatory mediators like inducible nitric oxide synthase and TNF $\alpha$, along with translocation of nuclear factor E2 p45-related factor 2 and upregulation of Heme oxygenase-1 [22]. Administration of C. quadrangularis extract significantly attenuated the gastric lesions induced by aspirin and this was accompanied by the rise in uric acid, antioxidative enzymes, $\mathrm{SH}$ groups, and a significant decrease in lipid peroxidase, TNF-alpha, myeloperoxidase and xanthine oxidase activities [23]. Kanwar, et al. [24] confirmed the anti-inflammatory and cartilageregenerative properties of $C$. quadrangularis and its mode of action via the inhibition of matrix metalloproteinase and reactive oxygen species. Hydroalcoholic extract of the plant treatment also reduced serum TNF- $\alpha$ level, oxidative stress and synovial expression of inflammatory and angiogenesis marker [25].

\section{Anti-obesity activity}

Aqueous leaf and stem extract of C. quandrangularis at 300 mg dose was effective in reducing body fat as well as improving blood parameters associated with metabolic syndrome [26]. Similarly, it was effective in reducing weight, improving blood parameters associated with metabolic syndrome, as well as serotonin levels in obese and overweight individuals [27]. Ross [28] reported that effectiveness of $C$. quandrangularis in the management of obesity and complications associated with metabolic syndrome. The plant also demonstrated efficacy in the control and lowering of triglyceride, total cholesterol, low-density lipoprotein cholesterol, and fasting blood glucose levels [29]. C. quadrangularis inhibited lipid accumulation without showing cytotoxicity to 3T3-L1 adipocytes [30]. Further, it decreased adipogenesis/lipogenesis-related mRNA expression levels of fatty acid binding protein, fatty acid synthase, lipoprotein lipase, stearoyl-CoA desaturase-1, and acetyl-CoA carboxylase. The results suggested that the plant have an anti-obesity effect by its ability to decrease expression levels of adipogenesis/lipogenesis-related genes and proteins.

\section{Anti-oxidant activity}

Ethanolic extract of $C$. quadrangularis exhibited significant scavenging effect on DPPH free radical, superoxide radical, hydroxyl radical production, and inhibition of lipid peroxide production in erythrocytes [31]. Further, the extract upregulates superoxide dismutase, glutathione peroxidase and endothelial nitric oxide synthase expression in hydrogen peroxide-injured human ECV304 cells [32]. Extracts of $C$. quadrangularis significantly and dose-dependently increased 
the latency to clonic and generalized tonic-clonic seizures and decreased the number and duration of seizures. Anticonvulsant activities of the plant are accompanied by its anxiolytics effects which are supported by its antioxidant properties and mediated [33]. C. quadrangularis being rich in antioxidants such as vitamin $\mathrm{C}$ and flavonoids was studied for its effect on the antioxidant system of femur in ovariectomized rats by Muthusami, et al. [34]. The extract prevented ovariectomy induced oxidative stress in the femur.

\section{Bone Turnover activity}

C. quadrangularis was tested for its bone protective properties and studied to discern the mechanism by which it is beneficial to bone [35]. It had protected the microarchitecture of the long bones from ovariectomy-induced bone loss because of decreased inflammation and modulation through the bone morphogenetic protein and Wingless-related integration site (Wnt) signaling pathways. The results indicated that the plant is a potential therapeutic agent to treat postmenopausal osteoporosis with no side effects. Petroleum ether extract of $C$. quadrangularis significantly increased the thickness of both cortical and trabecular bone suggesting the strong anti-osteoporotic activity of the plant. In addition, the extract reduced bone loss, as evidenced by the weight gain in femur, and also reduced the osteoclastic activity there by facilitating bone formation [36,37]. Also, percentage of the total length of ossified cartilage (bone) in pups were higher suggesting that maternal administration of $C$. quadrangularis petroleum ether extract during pregnancy can stimulate the development of fetal bone growth during the intra-uterine developmental period [38]. In another study, ethanol extract showed significant restorative progress with mineralization along with fairly well distributed osteocytes as well as complete recovery with essential features of normal bone [39].

Tasadduq, et al. [40] examined the effectiveness of $C$. quadrangularis in promoting osteoblast differentiation of the murine pre-osteoblast cell lines. The ethanolic extract augmented osteoblast differentiation, as reflected by a substantial increase in expression of the early osteoblast marker alkaline phosphatase activity. Osteogenic potential of Cissus was studied by Toor, et al. [41] and ethanolic extract of the plant accelerated fracture healing as well as early remodeling of fracture callus. The authors also studied the effect of hexane and dichloromethane fraction on the differentiation and mineralization of mouse pre-osteoblast cell line [42].

C. quadrangularis treatment has increased the DNA synthesis of human osteoblastic SaOS-2 cells indicating increased proliferation of these cells [43]. The study also revealed that the anabolic actions of ethanolic extract of $C$. quadrangularis in human osteoblast like cells are mediated through increased mRNA and protein expression of Runx2, a key transcription factor involved in the regulation of bone matrix protein. Osteogenic potential of $C$. quadrangularis on the mandibular fracture healing was studied by and the plant helps in reducing pain, swelling, and fracture mobility and accelerate the healing of fracture jaw bones $[44,45]$.

\section{Cardiovascular activity}

In a study by Oben, et al. [46], C. quandrangularis brought about significant reductions in weight and blood glucose levels, while decreasing serum lipids thus improving cardiovascular risk factors.

\section{Hepatoprotective activity}

Swamy, et al. [47] investigated the hepatoprotective activity of methanol extract of $C$. quadrangularis against rifampicin-induced hepatotoxicity in rats. It was concluded that the mechanism of hepatoprotection may be attributed to its antioxidant activity especially the presence of $\beta$-carotene. The plant affords hepatoprotection by its antioxidant and insulin-sensitizing activities [48]. It also showed antilipid peroxidative, free-radical scavenging property and ameliorated the liver damage by an increase in antioxidant enzymes activities [23].

\section{Conclusion}

Evidence from the previous studies suggested the efficacy of $C$. quadrangularis in treating various ailments. The major pharmacological activities of the plant include antimicrobial, anti-diabetic, anti-inflammatory, anti-obesity, anti-oxidant, bone turnover, cardiovascular and hepatoprotective. Further, the most extensive clinical studies using standardized extracts of Cissus alone or in combination with other ingredients involve weight loss and the regulation of blood glucose and lipids. Thus, Cissus quadrangularis appears worthy of pharmacological investigations for new drug formulations.

\section{References}

1. Oben J, Kuate D, Agbor G, Momo C, Talla X. The use of a Cissus quadrangularis formulation in the management of weight loss and metabolic syndrome, Lipids in Health and Disease. 2016; 5: 24-29. PubMed: https://pubmed.ncbi.nlm.nih.gov/16948861/

2. The Wealth of India, A Dictionary of Indian Raw Materials and Industrial Products. The Indian Medical Gazette, 1949; 84: 476-477. PubMed: https://www.ncbi.nlm.nih.gov/pmc/articles/PMC5189551/

3. Viswanatha Swamy AHM, Thippeswamy AHM, Manjula DV, Mahendra Kumar CB. Some neuropharmacological effects of the methanolic root extract of Cissus quadrangularis in mice. African J Biomed Res. 2006; 9: 69-75.

4. Mehta M, Kaur N, Bhutani KK. Determination of marker constituents from Cissus quadrangularis Linn. and their quantitation by HPTLC and HPLC. Phytochemical Analysis. 2001; 12: 91-95. PubMed: https://pubmed.ncbi.nlm.nih.gov/11705245/

5. Mishra G, Srivastava S, Nagori B. Pharmacological and therapeutic activity of Cissus quadrangularis: an overview. Int J PharmTech Res. 2003; 2: 1298-1310.

6. Stohs SJ, Ray SD. A review and evaluation of the efficacy and safety of Cissus quadrangularis extracts. Phytother Res. 2013; 27: 1107-1114. PubMed: https://pubmed.ncbi.nlm.nih.gov/22976133/ 
7. Sawangjit R, Puttarak P, Saokaew S, Chaiyakunapruk N. Efficacy and Safety of Cissus quadrangularis L. in Clinical Use: A Systematic Review and Meta-analysis of Randomized Controlled Trials. Phytother Res. 2017; 31: 555-567.

PubMed: https://pubmed.ncbi.nlm.nih.gov/28165166/

8. Kumar P, Dev K, Sharma K, Sahai M, Maurya R. New lignan glycosides from Cissus quadrangularis stems. Nat Product Res. 2019; 33: 233-238. PubMed: https://pubmed.ncbi.nlm.nih.gov/29488392/

9. Austin A, Jegadeesan M, Gowrishankar R. In-vitro screening of Cissus quadrangularis $L$. variant II against Helicobacter pylori. Ancient Science of Life. 2003; 23: 55-60.

PubMed: https://pubmed.ncbi.nlm.nih.gov/22557114/

10. Murthy KNC, Vanitha A, Swamy MM, Ravishankar GA. Antioxidant and antimicrobial activity of Cissus quadrangularis L. J Med Food. 2003; 6: 99-105.

PubMed: https://pubmed.ncbi.nlm.nih.gov/12935320/

11. Devipriya D, Roopan SM. Cissus quadrangularis mediated ecofriendly synthesis of copper oxide nanoparticles and its antifungal studies against Aspergillus niger, Aspergillus flavus. Materials Science and Engineering. C, Materials for Biological Applications. 2017; 80: 38-44. PubMed: https://pubmed.ncbi.nlm.nih.gov/28866178/

12. Gopinath V, Priyadarshini S, Meera Priyadharsshini N, Pandian $\mathrm{K}$, Velusamy $\mathrm{P}$. Biogenic synthesis of antibacterial silver chloride nanoparticles using leaf extracts of Cissus quadrangularis Linn. Materials Letters. 2013; 91: 224-227.

13. Marquis G, Ramasamy B, Banwarilal S, Munusamy AP. Evaluation of antibacterial activity of plant mediated $\mathrm{CaO}$ nanoparticles using Cissus quadrangularis extract. J Photochem Photobiol B: Biol. 2016; 155: 28-33. PubMed: https://pubmed.ncbi.nlm.nih.gov/26723000/

14. Zenebe S, Feyera T, Assefa S. In vitro anthelmintic activity of crude extracts of aerial parts of Cissus quadrangularis $L$. and leaves of Schinus molle L. against Haemonchus contortus. BioMed Res Int. 2017; Article ID 1905987: 6.

PubMed: https://pubmed.ncbi.nlm.nih.gov/29410960/

15. Muthu S, Gopal VB, Karthik SN, Sivaji P, Malairaj S, et al. Antibacterial cysteine protease from Cissus quadrangularis $\mathrm{L}$. Int $\mathrm{J}$ Biological Macromolecules. 2017; 103: 878-888.

PubMed: https://pubmed.ncbi.nlm.nih.gov/28539266/

16. Balasubramanian $P$, Jayalakshmi K, Vidhya N, Prasad R, Sheriff AK, et al. Antiviral activity of ancient system of ayurvedic medicinal plant Cissus quadrangularis L. (Vitaceae). J Basic Clin Pharm. 2009; 1: 37-40. PubMed: https://pubmed.ncbi.nlm.nih.gov/25206252/

17. Lekshmi RK, Rajesh R, Mini S. Ethyl acetate fraction of Cissus quadrangularis stem ameliorates hyperglycaemia-mediated oxidative stress and suppresses inflammatory response in nicotinamide/ streptozotocin induced type 2 diabetic rats. Phytomedicine. Int J Phytother Phytopharmacol. 2015; 22: 952-960.

PubMed: https://pubmed.ncbi.nlm.nih.gov/26321745/

18. Lekshmi RK, Divya BT, Mini S. Cissus quadrangularis extract attenuates hyperglycaemia-mediated oxidative stress in streptozotocin-induced diabetic rats. Redox report: Communications in Free Radical Res. 2014; 19: 214-220.

PubMed: https://pubmed.ncbi.nlm.nih.gov/24946070/

19. Panthong A, Supraditaporn W, Kanjanapothi D, Taesotikul T, Reutrakul V. Analgesic, anti-inflammatory and venotonic effects of Cissus quadrangularis Linn. J Ethnopharmacol. 2007; 110: 264-270. PubMed: https://pubmed.ncbi.nlm.nih.gov/17095173/

20. Shadmani A, Rizwani GH, Ahmed M. Potential anti-inflammatory effect of Cissus quadrangularis $L$. and Lepedium sativum $L$. along with their combination extracts. Pakistan J Pharmaceut Sci. 2018; 31: 2119-2122. PubMed: https://pubmed.ncbi.nIm.nih.gov/30393221/

21. Srisook K, Palachot M, Mongkol N, Srisook E, Sarapusit S. Antiinflammatory effect of ethyl acetate extract from Cissus quadrangularis Linn may be involved with induction of heme oxygenase-1 and suppression of NF-kB activation. J Ethnopharmacol. 2011; 133: 1008-1014.

PubMed: https://pubmed.ncbi.nlm.nih.gov/21094244/
22. Bhujade AM, Talmale S, Kumar N, Gupta G, Reddanna P, et al. Evaluation of Cissus quadrangularis extracts as an inhibitor of COX, 5-LOX, and proinflammatory mediators. J Ethnopharmacol. 2012; 141: 989-996. PubMed: https://pubmed.ncbi.nlm.nih.gov/22484053/

23. Jainu M, DeviCSS. Attenuation of neutrophil infiltration and proinflammatory cytokines by Cissus quadrangularis: a possible prevention against gastric ulcerogenesis. J Herb Pharmacother. 2005; 5: 33-42.

PubMed: https://pubmed.ncbi.nlm.nih.gov/16520296/

24. Kanwar JR, Samarasinghe RM, Kumar K, Arya, R, Sharma, S, et al. Cissus quadrangularis inhibits IL-1 $\beta$ induced inflammatory responses on chondrocytes and alleviates bone deterioration in osteotomized rats via p38 MAPK signaling. Drug Design, Devel Ther. 2015; 9: 2927-2940. PubMed: https://pubmed.ncbi.nlm.nih.gov/26089642/

25. Kumar R, Gupta YK, Singh S, Arunraja S. Cissus quadrangularis attenuates the adjuvant induced arthritis by down regulating proinflammatory cytokine and inhibiting angiogenesis. J Ethnopharmacol. 2015; 175: 346-355.

PubMed: https://pubmed.ncbi.nlm.nih.gov/26342521/

26. Nash R, Azantsa B, Kuate D, Singh H, Oben J. The use of a stem and leaf aqueous extract of Cissus quadrangularis (CQR-300) to reduce body fat and other components of metabolic syndrome in overweight participants. J Alternative Complementary Med. 2019; 25: 98-106. PubMed: https://pubmed.ncbi.nlm.nih.gov/29912570/

27. Kuate D, Nash RJ, Bartholomew B, Penkova Y. The use of Cissus quadrangularis (cqr-300) in the management of components of metabolic syndrome in overweight and obese participants. Nat Product Communications. 2015; 10: 1281-1286. PubMed: https://pubmed.ncbi.nlm.nih.gov/26411031/

28. Ross SM. Metabolic syndrome: a proprietary extract of Cissus quadrangularis formulation in the management of metabolic syndrome, weight loss, and central obesity. Holistic Nurs Practice. 2012; 26: 228-230. PubMed: https://pubmed.ncbi.nlm.nih.gov/22694868/

29. Oben J, Kuate D, Agbor G, Momo C, Talla X. The use of a Cissus quadrangularis formulation in the management of weight loss and metabolic syndrome. Lipids in Health Dis. 2006; 5: 24. PubMed: https://pubmed.ncbi.nlm.nih.gov/16948861/

30. Lee HJ, Le B, Lee DR, Choi BK, Yang SH. Cissus quadrangularis extract (CQR-300) inhibits lipid accumulation by downregulating adipogenesis and lipogenesis in 3T3-L1 cells. Toxicol Reports. 2018; 5: 608-614. PubMed: https://pubmed.ncbi.nlm.nih.gov/29854631/

31. Jainu M, Devi CSS. In vitro and in vivo evaluation of free radical scavenging potential of Cissus quadrangularis. Pharmaceut Biol. 2005; 43: 773-779.

32. Sapsrithong T, Kaewprem W, Tongumpai S, Nusuetrong P, Meksuriyen D. Cissus quadrangularis ethanol extract upregulates superoxide dismutase, glutathione peroxidase and endothelial nitric oxide synthase expression in hydrogen peroxide-injured human ECV304 cells. J Ethnopharmacol. 2012; 143: 664-672.

PubMed: https://pubmed.ncbi.nlm.nih.gov/22902249/

33. Moto F, Arsaa A, Ngoupaye GT, Taiwe GS, Njapdounke J, et al. Anxiolytic and Antiepileptic Properties of the Aqueous Extract of Cissus quadrangularis (Vitaceae) in Mice Pilocarpine Model of Epilepsy. Frontiers Pharmacol. 2018; 9: 751.

PubMed: https://pubmed.ncbi.nlm.nih.gov/30065650/

34. Muthusami S, Gopalakrishnan V, Stanley JA, Krishnamoorthy S, llangovan $\mathrm{R}$, et al. Cissus quadrangularis prevented the ovariectomy induced oxidative stress in the femur of adult albino rats. Biomed Pharmacother. 2016; 81: 416-423.

PubMed: https://pubmed.ncbi.nlm.nih.gov/27261621/

35. Guerra JM, Hanes MA, Rasa C, Loganathan N, Innis-Whitehouse W, et al. Modulation of bone turnover by Cissus quadrangularis after ovariectomy in rats. J Bone Mineral Metabol. 2019; 37: 780-795. PubMed: https://pubmed.ncbi.nlm.nih.gov/30756174/ 
36. Potu BK, Nampurath GK, Rao MS, Bhat KM. Effect of Cissus quadrangularis Linn on the development of osteopenia induced by ovariectomy in rats. La Clinica terapeutica. 2011; 162: 307-312.

37. Potu BK, Rao MS, Nampurath GK, Chamallamudi MR, Prasad K, et al. Evidence-based assessment of antiosteoporotic activity of petroleumether extract of Cissus quadrangularis Linn. on ovariectomy-induced osteoporosis. Upsala J Med Sci. 2009; 114: 140-148.

PubMed: https://pubmed.ncbi.nlm.nih.gov/19736603/

38. Potu BK, Rao MS, Kutty NG, Bhat KM, Chamallamudi MR, et al. Petroleum ether extract of Cissus quadrangularis (Linn.) stimulates the growth of fetal bone during intra uterine developmental period: a morphometric analysis. Clinics (Sao Paulo, Brazil). 2008; 63: 815-820. PubMed: https://pubmed.ncbi.nlm.nih.gov/19061006/

39. Shirwaikar A, Khan S, Malini S. Antiosteoporotic effect of ethanol extract of Cissus quadrangularis Linn. on ovariectomized rat. J Ethnopharmacol. 2003; 89: 245-250.

PubMed: https://pubmed.ncbi.nIm.nih.gov/14611887/

40. Tasadduq R, Gordon J, Al-Ghanim KA, Lian JB, Van Wijnen AJ, et al Ethanol extract of Cissus quadrangularis enhances osteoblast differentiation and mineralization of murine pre-osteoblastic MC3T3-E1 Cells. J Cellular Physiol. 2017; 232: 540-547.

PubMed: https://pubmed.ncbi.nlm.nih.gov/27264191/

41. Toor RH, Malik S, Qamar H, Batool F, Tariq M, et al. Osteogenic potential of hexane and dichloromethane fraction of Cissus quadrangularis on murine preosteoblast cell line MC3T3-E1 (subclone 4). J Cellular Physiol. 2019; 234: 23082-23096.

PubMed: https://pubmed.ncbi.nlm.nih.gov/31131449/

42. Toor RH, Tasadduq R, Adhikari A, Chaudhary MI, Lian JB, et al. Ethyl acetate and $n$-butanol fraction of Cissus quadrangularis promotes the mineralization potential of murine pre-osteoblast cell line MC3T3-E1 (sub-clone 4). J Cellular Physiol. 2019; 234: 10300-10314.

PubMed: https://pubmed.ncbi.nIm.nih.gov/30443977/

43. Muthusami S, Senthilkumar K, Vignesh C, Ilangovan R, Stanley J, et al. Effects of Cissus quadrangularis on the proliferation, differentiation and matrix mineralization of human osteoblast like SaOS-2 cells. J Cellular Biochem. 2011; 112: 1035-1045.

PubMed: https://pubmed.ncbi.nlm.nih.gov/21308732/

44. Singh V, Singh N, Pal US, Dhasmana S, Mohammad S, et al. Clinical evaluation of Cissus quadrangularis and Moringa oleifera and osteoseal as osteogenic agents in mandibular fracture. Natl $\mathrm{J}$ Maxillofac Surg. 2011; 2: 132-136.

PubMed: https://pubmed.ncbi.nlm.nih.gov/22639499/

45. Brahmkshatriya HR, Shah KA, Ananthkumar GB, Brahmkshatriya MH. Clinical evaluation of Cissus quadrangularis as osteogenic agent in maxillofacial fracture: A pilot study. Ayu. 2015; 36: 169-173. PubMed: https://pubmed.ncbi.nlm.nih.gov/27011718/

46. Oben JE, Enyegue DM, Fomekong GI, Soukontoua YB, Agbor GA. The effect of Cissus quadrangularis (CQR-300) and a Cissus formulation (CORE) on obesity and obesity-induced oxidative stress. Lipids Health Dis. 2007; 6: 4.

PubMed: https://pubmed.ncbi.nlm.nih.gov/17274828

47. Swamy AH, Kulkarni RV, Koti BC, Gadad PC, Thippeswamy AH, et al. Hepatoprotective Effect of Cissus quadrangularis Stem Extract Against Rifampicin-induced Hepatotoxicity in Rats. Indian J Pharmaceut Sci. 2012; 74: 183-187.

PubMed: https://pubmed.ncbi.nIm.nih.gov/23326004/

48. Chidambaram J, Venkatraman CA. Cissus quadrangularis stem alleviates insulin resistance, oxidative injury and fatty liver disease in rats fed high fat plus fructose diet. Food and chemical toxicology: an international journal published for the British Industrial Biological Research Association. 2010; 48: 2021-2029. PubMed: https://pubmed.ncbi.nlm.nih.gov/20450951/ 